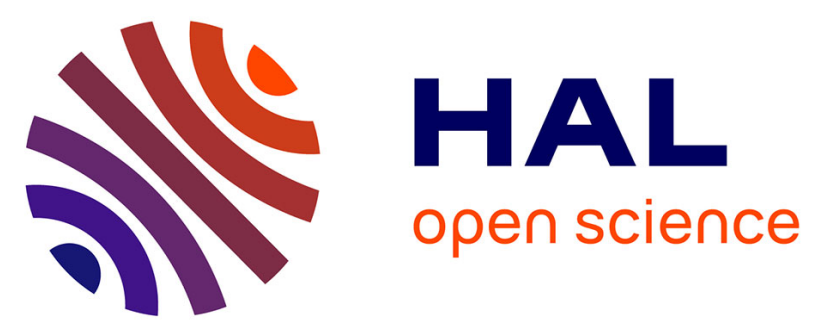

\title{
A Tool to Determine Annual Ground-Water Allocations in the Tarn-et-Garonne Alluvial Aquifer (France)
}

Pierre Le Cointe, Nuttinck, Vorlette, Jean-Daniel Rinaudo

\section{To cite this version:}

Pierre Le Cointe, Nuttinck, Vorlette, Jean-Daniel Rinaudo. A Tool to Determine Annual GroundWater Allocations in the Tarn-et-Garonne Alluvial Aquifer (France). Sustainable groundwater management: a comparative analysis of French and Australian policies and implications to other countries, pp.253-274, 2020, 10.1007/978-3-030-32766-8_13 . hal-02531770

\section{HAL Id: hal-02531770 \\ https://hal.science/hal-02531770}

Submitted on 3 Apr 2020

HAL is a multi-disciplinary open access archive for the deposit and dissemination of scientific research documents, whether they are published or not. The documents may come from teaching and research institutions in France or abroad, or from public or private research centers.
L'archive ouverte pluridisciplinaire HAL, est destinée au dépôt et à la diffusion de documents scientifiques de niveau recherche, publiés ou non, émanant des établissements d'enseignement et de recherche français ou étrangers, des laboratoires publics ou privés. 


\title{
Chapter 13. A tool to determine annual ground- water allocations in the Tarn-et-Garonne alluvial aquifer (France)
}

\author{
Pierre Le Cointe ${ }^{1}$, Vorlette Nuttinck ${ }^{2}$, Jean-Daniel Rinaudo ${ }^{3}$
}

1. BRGM (French Geological Survey), Toulouse, France

2. Direction Départementale des Territoires du Tarn et Garonne, Montauban, France

3. BRGM (French Geological Survey), Montpellier University, Montpellier, France

Corresponding author: p.lecointe@brgm.fr)

\begin{abstract}
The Tarn-et-Garonne department is crossed by three main rivers (Garonne, Tarn and Aveyron) whose alluvial plain covers an area of almost $1000 \mathrm{~km}^{2}$. Since 1996 , the "Direction Départementale des Territoires" (Gov. Administration at department level), with the technical help of the French geological survey (BRGM), initiated the development of a groundwater model and a spreadsheet tool to define annual groundwater abstraction allocations. As the field data and the computing capacities increased and the law evolved, three versions of the groundwater model were successively developed to better assess the Maximum Permissible Volumes (MPV) of groundwater abstraction on a yearly basis. The last transient state version takes into account the annual fluctuations in groundwater recharge and the water exchanges between the aquifer and the rivers. The MPVs are calculated each year in 21 management zones outside of the previously defined riverside aquifer. These zones are now managed by four agricultural users' associations, known as collective management agencies (or OUGCs). Further improvement should lead to the spreadsheet tool being available online, to encourage OUGCs and farmers to be more proactive in managing the groundwater resource.
\end{abstract}

Keywords Alluvial aquifer, groundwater model, riverside aquifer, management tool, annual allocation, collective management. 


\section{Introduction}

This chapter presents the quantitative management system for groundwater resources that was set up in the 1990s in the Tarn-et-Garonne department in southwestern France. This region is agricultural and crop irrigation constitutes the principal use of groundwater. The groundwater resource is comprised of shallow alluvial aquifers with thus limited storage capacity. This makes them very sensitive to annual climatic fluctuations, which can be considerable in the department. In dry years, the decline in water levels causes certain boreholes to dry up, generating localised conflicts over water use. In addition, when groundwater is abstracted from the aquifer, baseflow is reduced which means that rivers lack that volume of water, exacerbating problems at low water levels for the three major rivers flowing through the department.

At the end of the 1990s amid mounting concerns, the Adour-Garonne Water Authority, the region and the state launched a programme designed to improve knowledge of the groundwater resource and to model how it functions. This led to the development of a water allocation tool used for issuing authorisations to farmers for abstraction on an annual basis. The most original feature of the tool is its capacity to adjust the volumes allocated to users at the start of each year, by taking into account the climatic conditions and aquifer recharge. Initially, the allocation process was the exclusive responsibility of the state, but gradually the users became involved.

This chapter presents the principal stages of implementing the groundwater management system. Section 1 describes the main characteristics of the study area, the groundwater resources and its uses. Section 2 presents the first management mechanism applied between 1996 and 2006, based on the allocation of authorisations expressed in terms of pumping flow rate. Section 3 describes the implementation of a volumetric management system, based on the calculation of a maximum permissible volume shared between users in the form of individual quotas. Section 4 recounts how a collective management approach emerged based on the creation of water user associations. The state transfers the responsibility of allocating volumes of water for abstraction to the user associations.

\section{Presentation of the case study}

\subsection{Geographic and climatic context}

Tarn-et-Garonne is a French department located in the Aquitaine Basin, in the southwest of the country. The alluvial plain covers an area of almost $1000 \mathrm{~km}^{2}$, which represents $30 \%$ of the land in the department. It is located at the confluence of three major rivers: the Tarn, the Garonne and the Aveyron. The altitude in the 
region varies between 50 and $210 \mathrm{~m}$. The plain is surrounded by hills composed of the Lomagne and White Quercy Tertiary molasses and, on its eastern border, by the karstic plateaux of Caylus Causse, which is a part of Quercy Causses (Figure 13. 1).

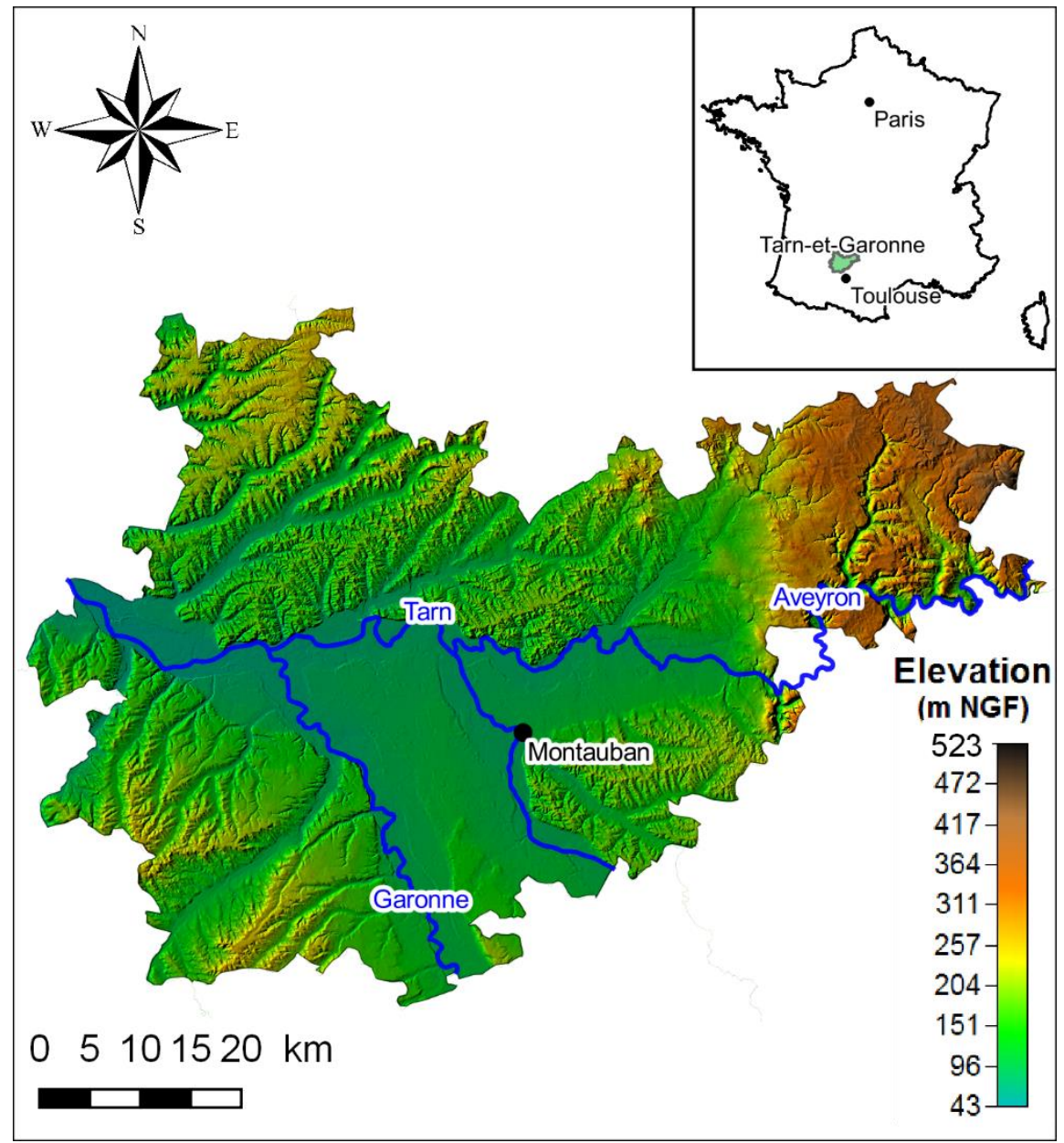

Figure 13. 1: Location and topography of the Tarn-et-Garonne department.

The climate is characterised by mild wet winters and hot, generally dry summers. Annual rainfall is around $700 \mathrm{~mm}$ and is relatively homogenous across the region. However, there is high inter-annual variation (ranging from $426 \mathrm{~mm}$ in 1967 to $1007 \mathrm{~mm}$ in 1959 at the station in Montauban), which leads to variations in aquifer recharge. 


\subsection{Geological context and the groundwater resource}

The confluence of the Garonne, Tarn and Aveyron Rivers consists of an extensive series of Quaternary alluvial deposits composed of sand and gravel deposited on Tertiary clay-limestone molasses formations, which are thought to be fairly impermeable (Bouroullec, 2013). The alluvial system comprises tiered terraces, created during a succession of glacial and interglacial phases. Because of erosion, the terraces are frequently separated by molasse banks, from which springs emerge (Figure 13. 2).

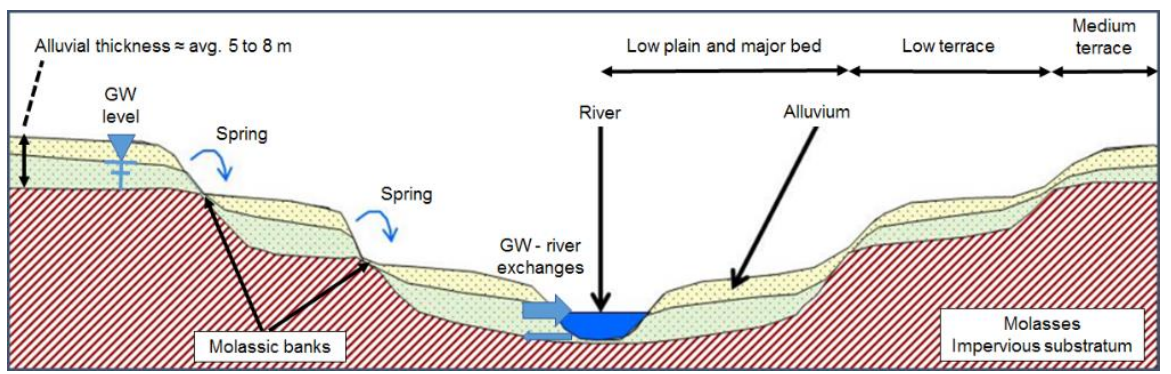

Figure 13. 2: Diagrammatic cross-section of the tiered terrace system.

The alluvium on the different terrace levels averages 5 to $8 \mathrm{~m}$ thick and form unconfined aquifers. These aquifers are mainly replenished by rainfall infiltration and contribute discharge to the watercourses by baseflow. The alluvial aquifer in Tarn-et-Garonne thus contributes on average to $3 \%$ of the total flow of rivers in the department, a contribution that rises to $8 \%$ during low-water periods.

\subsection{The uses of surface and groundwater}

The Tarn and Garonne Rivers represent a significant surface water resource for the department. Between 2003 and 2012, surface water provided $84 \%$ of the region's average water requirements $\left(87\right.$ million $\mathrm{m}^{3}$, excluding extraction for cooling the nuclear power plant), while groundwater supplied $16 \%$ of the requirements (16 million $\mathrm{m}^{3}$ ). The use of groundwater has declined significantly since the end of the 1990s, when the total volume abstracted reached 35 million $\mathrm{m}^{3}$ per year. 
Table 13. 1: Volumes of surface and groundwater abstracted in Tarn-et-Garonne Plain, per use (in thousands of $m 3$ per year). Average volume abstracted from 2006 to 2012 (Source: Bardeau et al, 2016).

$\begin{array}{lcc}\text { Sector } & \text { Groundwater } & \text { Surface water } \\ \text { Drinking water } & 4370 & 10968 \\ \begin{array}{l}\text { Industry } \\ \text { Agriculture } \quad \text { (irriga- }\end{array} & 1016 & 550 \\ \text { on) } & 10848 & 36289 \\ \text { Total } & 16235 & 87465\end{array}$




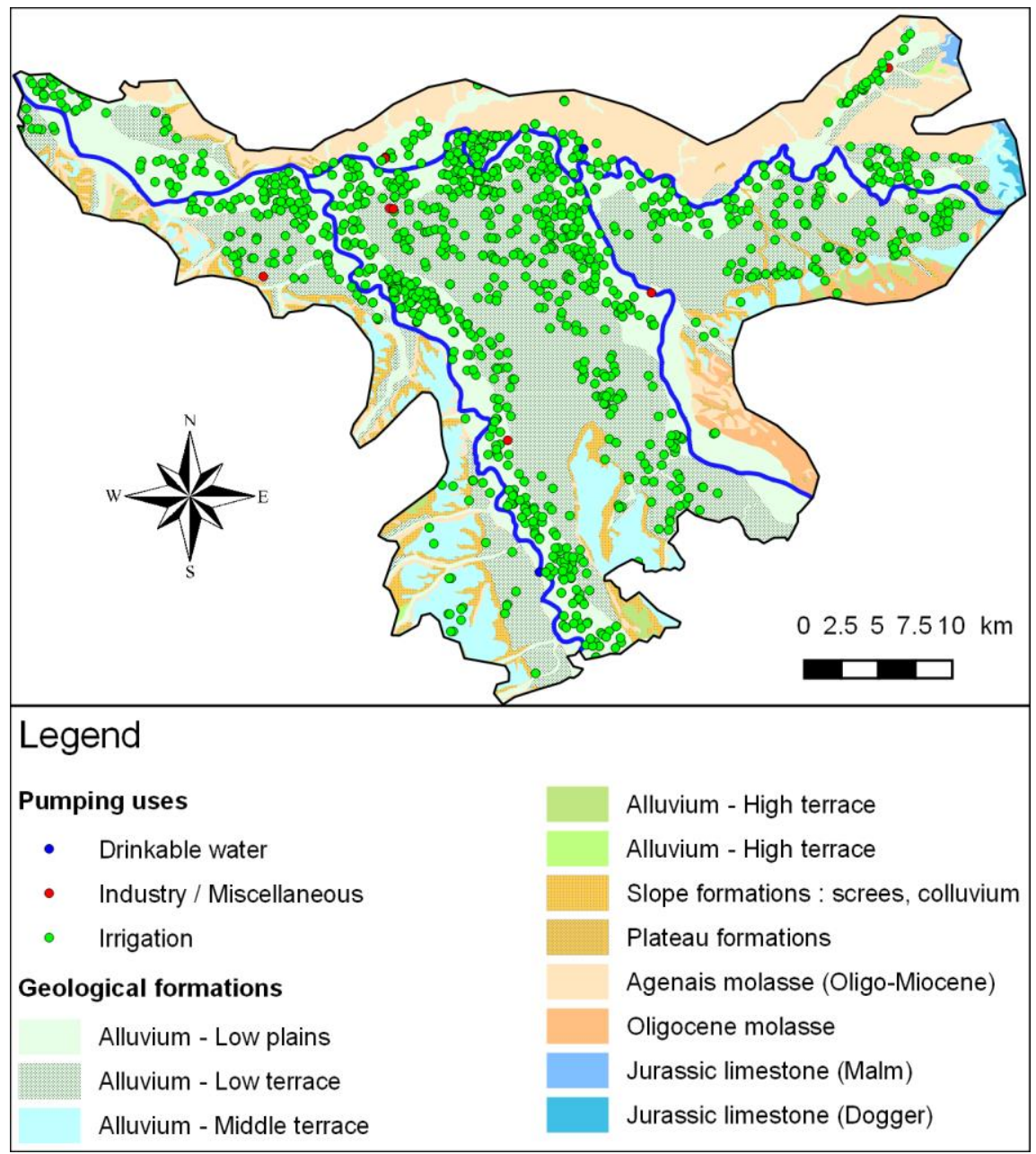

Figure 13. 3: Geographic distribution and use of groundwater abstracted from the alluvial aquifers in Tarn-et-Garonne in 2015.

The alluvial aquifers are primarily used by the agricultural sector for crop irrigation (71\% of volume abstracted). The remaining volume is used to supply drinking water $(26 \%)$ and several industries (3\%) (Table 13.1 ; 


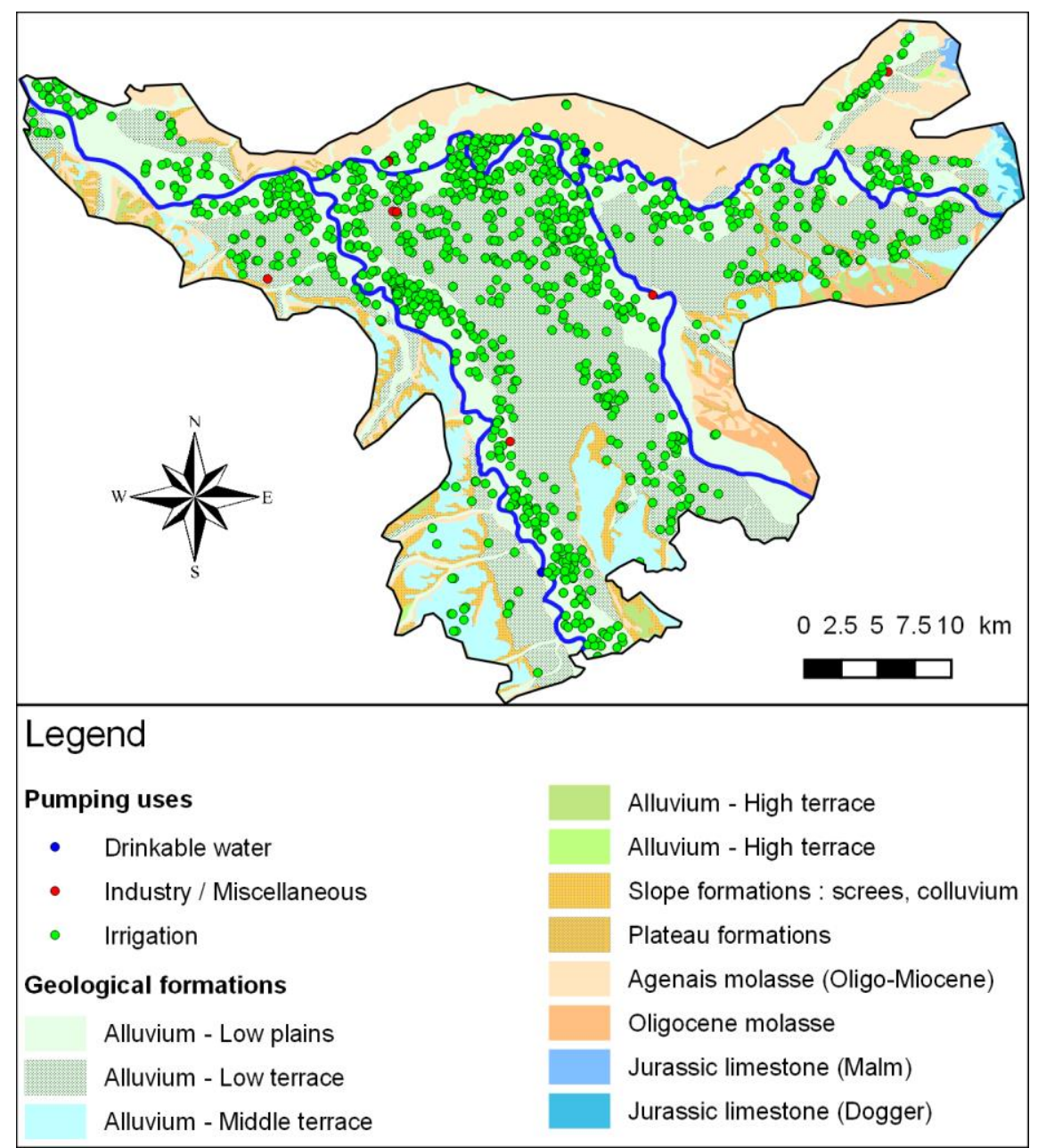

Figure 13.3).

Agriculture is important for the economy in Tarn-et-Garonne. The fruit sector, predominantly located on the alluvial plain, represents $11 \%$ of agricultural land in the department but generates $33 \%$ of production in value. Fruit crops are systematically irrigated, largely with water pumped from the main rivers (the Garonne, the Tarn and the Aveyron) or from the aquifer in the sectors with no access to surface water. The water is used for irrigation in the summer, but also to reduce frost damage in the spring.

The large arable farms (cereals, maize) comprise $40 \%$ of the farmland in the department, but only produce $22 \%$ of the output in value. Irrigation for arable crops is highly developed, although dry cultivation is still practiced. Irrigation primarily 
concerns maize, but also cereals (irrigated once or twice in spring for seedling emergence), sunflower and soya. Cereals and maize can be grown without irrigation in soils with sufficient available water.

As in most regions in France, farms are still family businesses. This equally applies to the largest farms, which may have over 350 ha of fruit trees. In Tarn-etGaronne, large and average-sized farms cover $86 \%$ of the utilised agricultural land and generate $95 \%$ of the output in value.

\subsection{The challenge of managing groundwater}

The alluvial aquifers in Tarn-et-Garonne have a limited storage capacity and react quickly to climatic fluctuations. In dry years, the combination of low recharge and high abstraction for crop irrigation lowers the groundwater level, potentially causing some wells or boreholes to dry up.

In addition, when a volume of water is abstracted from the aquifer, baseflow is reduced and the rivers lack that water, accentuating the problem of low water levels in watercourses. Nonetheless, this impact remains inconspicuous because the discharge in Tarn-et-Garonne rivers is largely determined by the dams located upstream of the area studied. The inflow from the aquifers to the rivers is marginal compared to the streamflow from upstream. Thus, the situation is very different from Beauce region (Chapter 6), where the over-exploitation of groundwater has caused some small watercourses to dry up completely.

\section{Managing abstraction based on flow rate: 1996- 2006}

For years, the use of groundwater was far less regulated than that of surface water. This situation actually encouraged groundwater use. Until the mid-1960s, the construction and use of wells or boreholes for irrigation were only subject to a declaration, in the case of works exceeding a depth of $10 \mathrm{~m}$, according to the Mining Code of 1951. With the 1964 law, a licence was required for installations that pumped over $80 \mathrm{~m}^{3} / \mathrm{h}$, while other installations simply had to be declared. Therefore, the use of groundwater for agricultural purposes developed in a context where there was virtually free access to the resource.

The gap between the regulations for using surface water and groundwater was further widened when the 1984 law came into force (the so-called "fishing" law). The law actually created a regulatory mechanism allowing state services to restrict surface water abstraction in the event of severely low water levels in order to protect aquatic habitats and fishery resources in particular. As the regulation did not apply to groundwater, many farmers replaced (or supplemented) their river water intake with a borehole in the alluvial aquifer, sometimes located only a few metres away 
from the riverbank. By relocating their point of abstraction, they evaded the temporary restrictions applied to the watercourses and continued pumping the same resource at little extra cost. This situation did not change until the 1992 Water Act came into force.

\subsection{The 1992 Water Act}

The 1992 Water Act radically changed how surface water and groundwater were managed in Tarn-et-Garonne. In general, the law set out to restore a balance between abstraction and available resources, by taking the health of aquatic habitats into account (see Chapter 3). Four of the provisions in the Water Act had a direct impact on water management in Tarn-et-Garonne.

The first provision introduced the concept of riverside aquifer, which was designed to take into account the impact of groundwater abstraction on the surrounding watercourses. The concept of riverside aquifer refers to an aquifer that is hydraulically connected to a watercourse. In most cases, the aquifer is contained in the existing alluvial deposits, previously deposited by the watercourse. When water is abstracted from the aquifer, there is a reduction in the flow of the watercourse at low water levels. This occurs because the aquifer supplies less water to the watercourse or because the latter starts supplying the aquifer (as a result of pumping). From a regulatory perspective, the law states that abstraction from the riverside aquifer should be considered as surface water abstraction. Therefore, it should be subject to the same regulatory restrictions where appropriate.

The second change was linked to the creation of water use restriction zones ("Zones de Répartition des Eaux", ZRE). These zones included the basins, sub-basins or aquifers characterised by a structural shortage of resources in relation to requirements. The regulatory zoning allowed the state to tighten restrictions. It became mandatory to declare abstraction points with a flow rate of $8 \mathrm{~m}^{3} / \mathrm{h}$ or more and if warranted, any new abstraction could be banned. The whole Tarn-et-Garonne department was declared a water use restriction zone in 1994.

The third major change was the obligation to install a volumetric meter at all abstraction points within five years. In Tarn-et-Garonne and more generally throughout southwestern France, the farming community was fiercely opposed to installing meters. Thus in 2005 , only $40 \%$ of water abstraction points were equipped with meters, but by the 2010 s, meters had been installed in $90 \%$ of abstraction points.

In Tarn-et-Garonne, the 1992 Water Act was only genuinely implemented in 1995. The state took the initiative, by appointing an inter-ministerial water commission (MISE) to issue water use permits. The MISE conducted the first survey of water abstraction (surface and groundwater) and developed a network of groundwater monitoring wells in the alluvial aquifers. A study was also launched to define the extent of the riverside aquifer and develop a groundwater flow model to simulate how the alluvial aquifer functions for different abstraction scenarios. In 1996, based 
on the newly acquired knowledge, the MISE issued the first individual annual permits for abstraction. The permits stipulated an authorised flow rate. The installation of the volumetric meters had only just begun for both surface and groundwater at that time, which ruled out the possibility of issuing volumetric authorisations for abstraction.

\subsection{Acquiring a knowledge base for alluvial aquifers}

When the state started introducing a management system for water abstraction, very little information was available on groundwater and its uses. The available knowledge was collated in the comprehensive hydrogeological study of the Tarnet-Garonne department, conducted in the framework of the assessment of the hydraulic resources of France (Soulé, 1978). The study contained an inventory of the department's wells, boreholes and springs, which was conducted over a two-year period, but had incomplete information about the aquifers' geometry and hydrogeological properties. There was insufficient data to establish a synchronous piezometric map.

In 1995, the first step involved acquiring supplementary data. The state conducted a census of the water abstraction points (surface and groundwater) which resulted in a large number of undeclared wells and boreholes being registered. In addition, a field survey was carried out and measurements obtained from the 387 wells were used to establish a piezometric map for the alluvial system in Tarn-etGaronne. The field survey also provided the opportunity to verify the abstraction data collected by the MISE and the Adour-Garonne Water Authority.

Since 1982, the water level in the alluvial aquifer was constantly monitored by a state service in an unused borehole in the lower Garonne Plain. This was the only long-term piezometric record available for the entire alluvial system in Tarn-et-Garonne at the time.

\subsection{Defining the riverside aquifer}

The available knowledge was applied to defining the boundary of the riverside aquifer. It was defined as "the aquifer(s) hydraulically connected to the watercourse and where abstraction is likely to have an impact (direct or indirect) on the river flow rate before the end of the low water period" (Collin and Daum, 1995). Therefore, the extent of the riverside aquifer depends on the choice of (i) the impact threshold for pumping groundwater on the river flow rate and (ii) the time t, after which the impact becomes apparent. In the case of the alluvial aquifer in Tarn-etGaronne, the riverside aquifer is initially defined using time $t=90$ days, which corresponds to the duration of the irrigation season. The impact threshold is calculated for two values, 1 and $5 \%$. This percentage is the ratio between the flow that is directly or indirectly deducted from the river, and the pumping flow rate.

Theis and Darcy's formulae were used to define the boundary of the riverside aquifer for the Garonne, the Tarn and the Aveyron and Rivers (Gandolfi et al., 
1997). The formulae presume that the values for the aquifer's transmissivity and storage coefficient are known. In the absence of accurate data, a single value was used for the entire lower plain for both parameters $\left(\mathrm{T}=2.5 \times 10^{-3} \mathrm{~m}^{2} / \mathrm{s} ; \mathrm{S}=4 \%\right)$. Identifying the boundaries of the riverside aquifer in this way revealed the zone was often 3 or $4 \mathrm{~km}$ wide and was hence limited to the lower plain of the main watercourses. It is considered the only alluvial terrace with groundwater-surface water connectivity (Figure 13. 4).

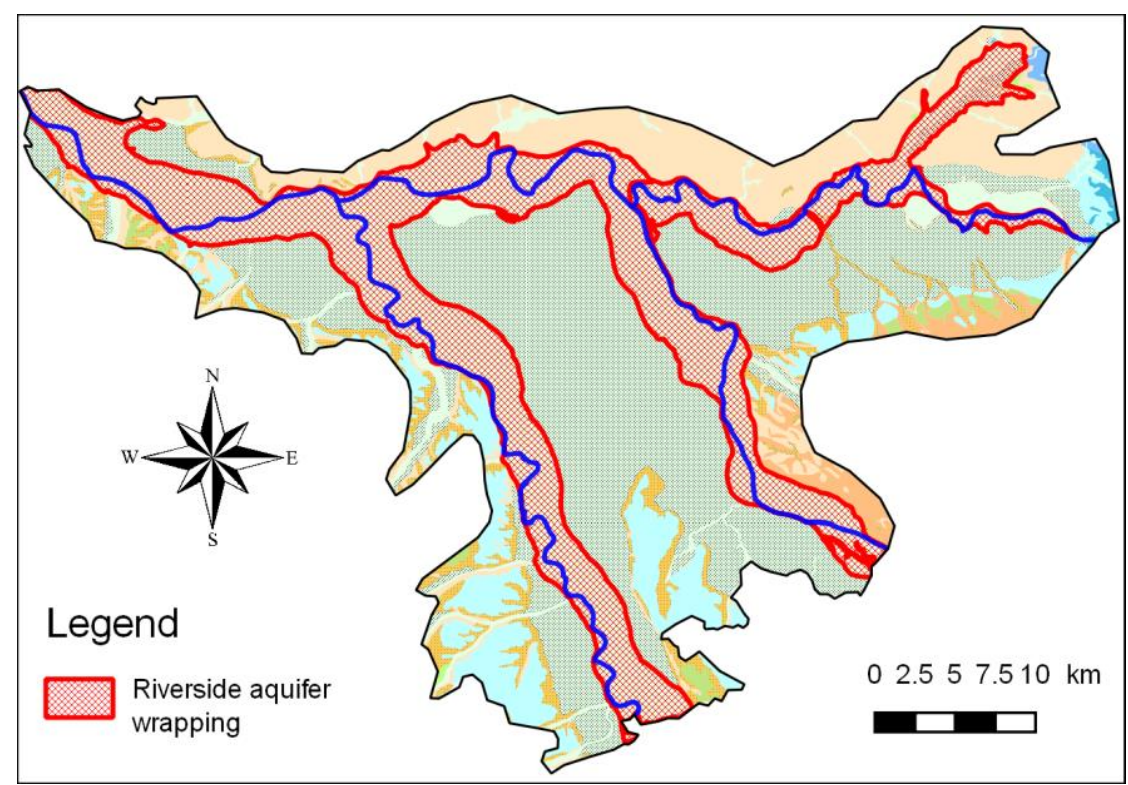

Figure 13. 4: The extent of the riverside aquifer in 1996 (source: Gandolfi et al., 1997).

\subsection{Developing the groundwater flow model}

The next step consisted in developing a groundwater flow model for the whole alluvial aquifer (Gandolfi et al., 1997). The aim was to develop a simulation tool to provide the MISE with the elements it required to issue abstraction permits for irrigation. The software MARTHE (Thiéry, 1990, 2015) was used for this model. It resolves the flow equation in porous media, which link flow rates to the groundwater levels (Darcy's law), on a rectangular grid using the finite difference method. A square grid $\left(1 \mathrm{~km}^{2}\right)$ was applied on the alluvial plain for a total of 895 computational grid cells. The presence of numerous boreholes in the zone meant that it was possible to describe correctly the aquifer's geometry.

The model's development was severely limited by the lack of data. Only one piezometric record was available when the first model was built, which ruled out 
the possibility of developing a transient state model that could reproduce the seasonal fluctuations in the groundwater level (as a function of rainfall and pumping). The first model (a steady state model) shows the average state of the aquifer during the low water period.

The model was adjusted for the low water period in 1996, using data collected during the field survey. The volumes abstracted in 1996 were estimated as annual average pumping rates, calculated to ensure that the abstracted volume corresponded to the whole year. An average recharge of $80 \mathrm{~mm}$ was estimated based on the rainfall record and the piezometric history of the only well monitored since 1982. The model was calibrated using permeability values, the parameter that had the least field measurements. These were based on the range of values used for the different terraces. Once calibrated, the model was capable of accurately reproducing the piezometric baseline (the low water period in 1996).

\subsection{From the model to the management tool for abstraction}

The mathematical model was then used to simulate the impact of different abstraction scenarios on the groundwater levels. In the simulations, the abstraction levels are increased uniformly by 20,50 and 100\% compared to the estimated 1996 level.

The results of the simulation show that a growing number of model grid cells are dewatered when pumping increases. Although aquifer dewatering is unlikely to occur in the field given the scale of the model, the findings indicate that the resources are limited or over-exploited in several sections of the alluvial aquifer.

The model was divided into 58 management zones (Figure 13. 5). These zones were defined in relation to the geology (distinction between different alluvial terraces), flow lines (distinction between the different hydrogeological catchment areas), the density of abstraction points (calculated by subdividing the heavily exploited zones) and the model's grid cells (the construction of zones with too few cells was avoided).

Based on the simulation results, the maximum permissible flow rate for irrigation was calculated for each zone that ensured that the aquifer was not dewatered in the simulations.

The results of the modelling were transposed to a simplified management tool that can be run using Excel. Once the tool has integrated the data, the abstraction authorisations can be updated and compared with the available resources to determine whether or not new abstraction authorisations can be issued. When first used in 1996, the tool revealed that in 10 out of 58 management zones, the authorised abstraction rate should have been reduced by a total of about $1000 \mathrm{~m}^{3} / \mathrm{h}$. On the other hand, the abstraction rates in 46 zones could have been increased to a total rate of $10000 \mathrm{~m}^{3} / \mathrm{h}$. These findings show that if abstraction were better managed in terms of spatial distribution, pumping rates could be increased by a further $40 \%$. 


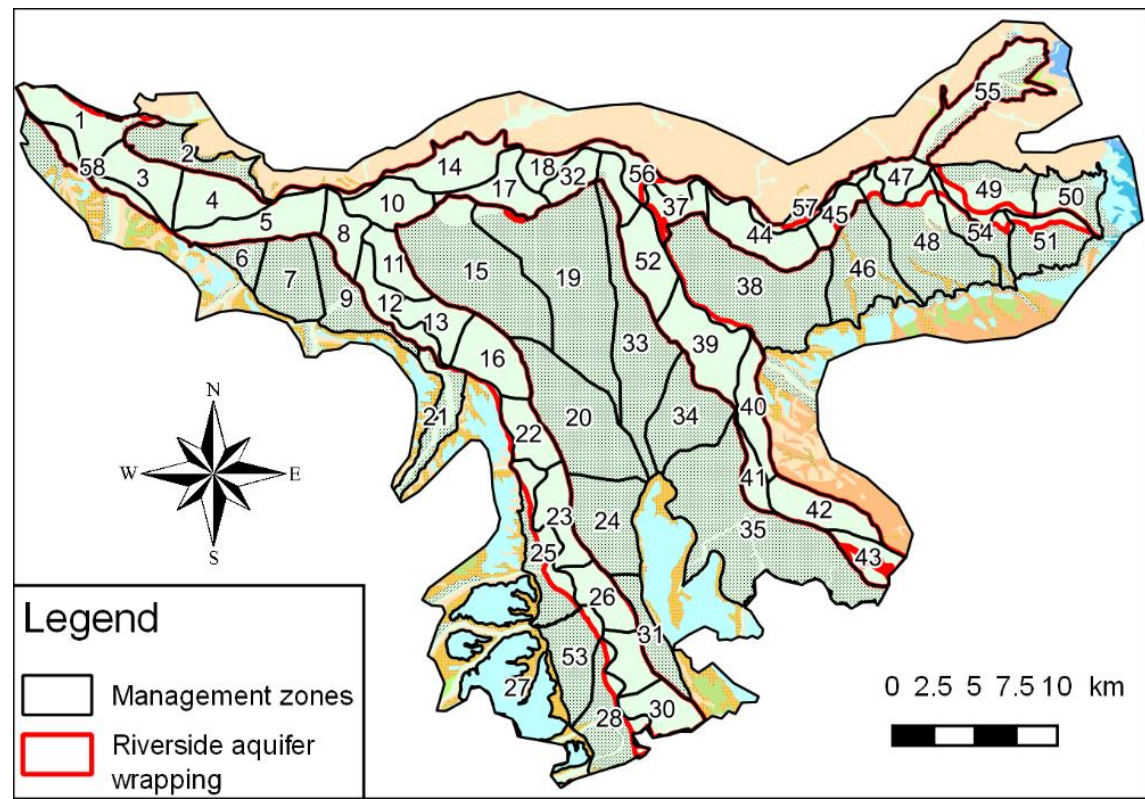

Figure 13. 5: Map of the 58 management zones for the alluvial aquifers in Tarnet-Garonne (source: Gandolfi et al., 1997).

\subsection{The procedure for allocating annual authorisations for abstraction}

Since 1996, this tool has been used by the MISE to determine the annual abstraction authorisations. The procedure was as follows (Figure 13.6):

1) In February before the irrigation season begins, each farmer submits their irrigation plan to the MISE, with details of the crops and the area of land that the farmer wants to irrigate, the pumping rate and the required volume. The MISE checks whether the plan is consistent with the license (maximum authorised abstraction rate) issued for the borehole. It also ascertains whether the pumping rates and volumes requested are consistent with the crops and the acreage concerned.

2) For each management zone, the MISE compares the total flow rate requested with the maximum permissible abstraction rate (estimated using the model). If the total request is less than the maximum rate, all the annual applications are accepted. The MISE can also accept new applications to install boreholes in these management zones.

3) However if the total request exceeds the maximum abstraction rate, the resource in the management zone is considered to be over-allocated. No new boreholes can be authorised in the zone and the annual applications cannot be 
fully satisfied. First, the MISE strives to meet the individual requests, by allocating the abstraction rate attributed in previous years. Then, it shares out what is left of the available resource if any, in proportion to the extra request. The MISE notifies each farmer of the authorised pumping rate before the start of the season.

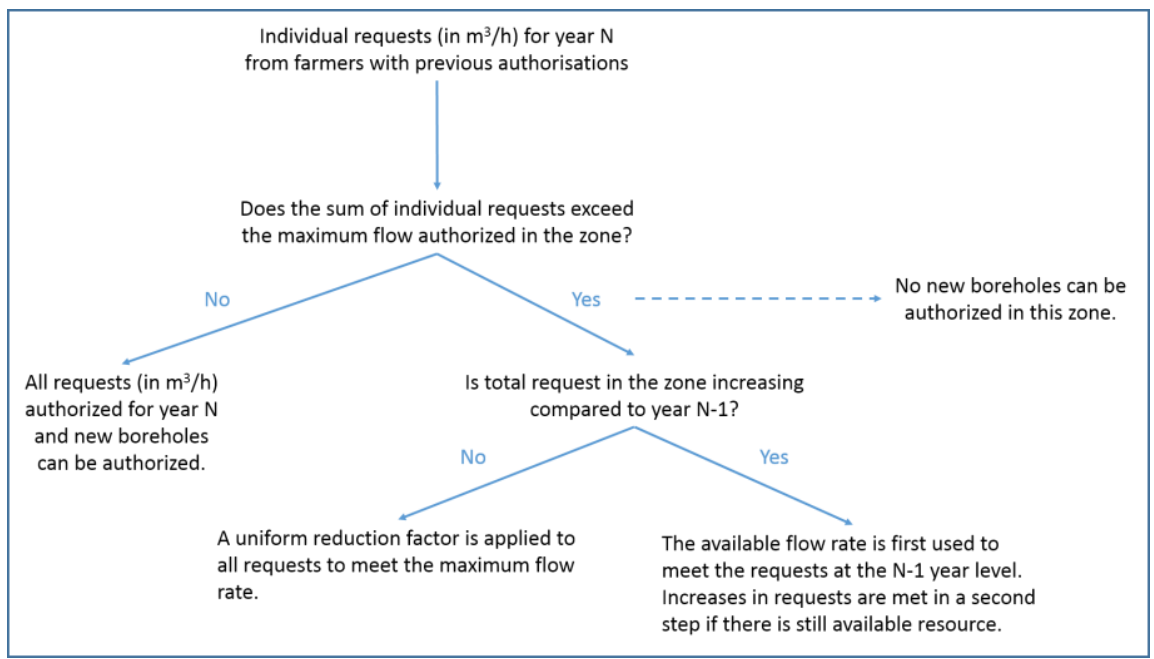

Figure 13. 6: Procedure for allocating the annual authorisations for abstraction, based on flow rate.

This procedure operated from 1996 to 2006. From the late 1990s, the Chamber of Agriculture processed the applications, which involved reception, compilation and verification (stage 1), and acted as the intermediary between farmers and the administration. In cases where the maximum abstraction rate allocated to certain management zones was exceeded, the Chamber of Agriculture negotiated with the applicants to reduce the requests for the highest abstraction rates. The negotiations involved stakeholders from the agricultural sector, not the administration, which meant there was more chance of the negotiations being successful.

Overall, during this period, few management zones experienced conflict situations where authorisations were refused.

\subsection{Limitations of the management procedure}

One of the procedure's limitations was that it failed to take into account the actual groundwater situation at the start of the season, when the farmers' annual allocation of resources was calculated. In fact, the model was not used each year to estimate the volumes genuinely available at the start of the season. Given that the alluvial 
aquifer is shallow and unconfined, the groundwater level is vulnerable to major fluctuations due to seasonal and inter-annual rainfall, which significantly modify the volume of water available for irrigation from year to year. As the management procedure was based on a steady state model, it could induce over-exploitation of the aquifer in some years if the volumes allocated were too high. On the contrary, it could unnecessarily restrict users in wet years. This observation, combined with regulatory changes and the acquisition of relevant data, led to a revision of the management model and the entire procedure for allocating annual pumping authorisations.

\section{Volumetric management of abstraction: 2007- 2015}

After the 2006 Water Act came into force, the state was obliged to implement a volumetric management system for abstraction in all the basins designated as restricted zones. The management tool used in Tarn-et-Garonne for allocating abstraction authorisations (expressed as flow rate) failed to meet these new requirements. As a result, the model and the management tool were overhauled, which involved collecting new data.

\subsection{Setting up a groundwater monitoring system}

Until 1996, the groundwater level was monitored at a single point. This was totally inadequate for measuring seasonal and inter-annual fluctuations in the groundwater level and especially for developing a transient state model.

To overcome this shortfall, two groundwater level monitoring networks were gradually set up (Ricard, 1998, Ricard and Tilloloy, 1999). The first was established between 1996 and 2005, which continuously measures and records the level in 10 monitoring wells equipped with telemetry. The second network comprises 26 other wells (16 were monitored regularly), where the state took manual measurements every 2 months (Figure 13. 7). In addition to groundwater monitoring, the flow rate and water levels were monitored in the main watercourses, using automatic hydrometric stations, combined with manual measurements taken in the three main rivers (the Garonne, the Tarn and the Aveyron). 


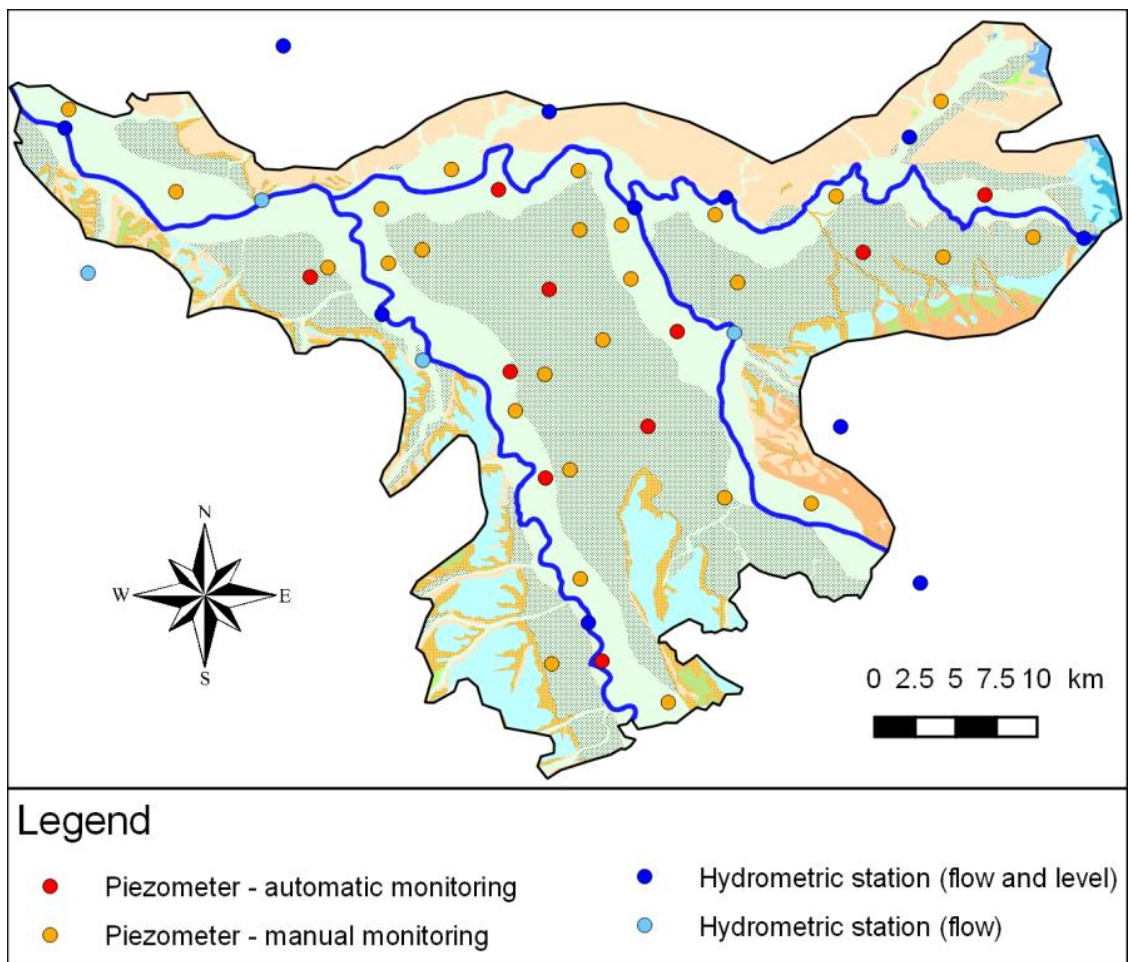

Figure 13. 7: Map of the groundwater and river monitoring network (source: Bardeau et al., 2016).

\subsection{The revision of the groundwater model}

These data were used to develop a new transient state model ${ }^{42}$ to estimate the water resource available each year from 2007 onwards (Ghyselinck-Bardeau, 2004a, 2004b, 2007). The model was capable of reproducing seasonal and interannual fluctuations in water levels by taking into account the variability in rainfall and the observed abstraction. The model's spatial resolution was also improved with a smaller grid of $250 \mathrm{~m}$.

Twelve scenarios of annual recharge were then designed using climatic data from the station in Montauban, including rainfall measurements since 1949. Seven scenarios of abstraction based on pumping rates for the year 2005 ( \pm 0 to $30 \%$ ) were also used. By combining these scenarios, 84 simulations were conducted to predict the groundwater level at the end of the irrigation period. The simulations were used

42 The model was calibrated based on the piezometric history for the period 1996-2005, with a bimonthly interval, i.e. the groundwater level was simulated every 2 months and abstraction for irrigation was allocated to June-July and August-September. 
to determine the volumes and rates of abstraction for 12 recharge scenarios. The new abstraction volumes and rates estimated with this model are higher on average than those derived from the tool used since 1996.

\subsection{A tool to assess the annual water allocation}

The results of all the simulations were integrated into a decision-making tool used by the MISE for allocating the annual authorisations for abstraction. The tool was developed using Excel and contains two modules. The MISE applies the first module to issue administrative approval for abstraction (in January) and the second to inform users of the actual volumes available in June (Saplairoles, 2005).

In January, when the administration has to issue authorisations for use, the aquifer's annual recharge is still underway. However, at this stage, farmers want some information to prepare their crop plan and decide on the area to plant. The MISE feeds data into the management tool for the total groundwater recharge between October and January, based on the recorded rainfall data, plus a hypothetical expected recharge for the next 3 months. The sum of the two provides a hypothetical, but probable, annual recharge. This value is compared to the 12 recharge scenarios simulated previously. The scenario that is the most similar to the current year (year $\mathrm{N}$ ) is used to determine the maximum volume for abstraction. The MISE compares this volume to the requests made by farmers and the drinking water services. It then applies the rules (described above) to determine the volumes allocated to each applicant when the authorisations are issued. The volume specified in the authorisation is provisional and subject to revision if spring rainfall is lower than expected.

The second module is used at the start of June, when the irrigation period begins. At this stage, the effective rainfall for the whole hydrological year is known (apart from a few exceptions, summer rainfall does not recharge aquifers). An estimate of the annual recharge can now be fed into the management tool. As previously, the scenario that is most comparable to year $\mathrm{N}$ is used to provide the volume that can be abstracted in each of the 58 management zones. If spring recharge is lower than expected, the volumes actually allocated are lower than those specified in the annual authorisation established in advance in January.

\subsection{Differentiating between water entitlements and allocation}

When the volume for abstraction has been estimated, it is shared between the users in proportion to the flow rate that they are authorised to abstract. A parallel can be drawn with the Australian management model, in which the authorisation (flow rate) allocated to users amounts to an "entitlement". In fact, it constitutes a long-term right of use, which gives access to a fraction of the available resource. Whereas the allocation is the annual volume that is estimated each year, after the volume for abstraction has been calculated (as presented above).

Table 13. 2 shows how individual allocations are assessed each year. At the start of year $\mathrm{N}$, the users inform the manager of their irrigation plan. They declare the 
share of their entitlement that they wish to activate (1) and the share that they do not intend to use (dormant entitlement) (2). The manager then calculates the total maximum request for year $\mathrm{N}(5)$, which is capped and allocated on a per unit basis set for each hydrographic basin (4). If total request exceeds the maximum permissible volume (6), a reduction coefficient must be applied to determine the actual allocation (9). It is important to note that users, who have deferred the use of a share of their entitlement one year, can activate it freely the following year.

Table 13. 2 presents two examples to illustrate the rationale applied in 2015: Zone 13, in the Garonne basin, where the resource was over-allocated; and Zone 14, in the Tarn basin, where the resource was under-allocated. In Zone 13, all the activated entitlements amounted to $1048 \mathrm{~m}^{3} / \mathrm{h}$. The maximum allocation $\left(833 \mathrm{~m}^{3} / \mathrm{m}^{3} / \mathrm{h}\right)$ could not be granted to users because the total corresponding volume $\left(872984 \mathrm{~m}^{3}\right)$ significantly exceeded the Maximum Permissible Volume (MPV), estimated at $284954 \mathrm{~m}^{3}$ in 2015 with the management tool. The actual allocation to the users was reduced to $358 \mathrm{~m}^{3} / \mathrm{m}^{3} / \mathrm{h}$. This corresponds to the MPV divided by the activated entitlement for the year 2015. On the other hand, in Zone 14, the users received the maximum allocation, which is $686 \mathrm{~m}^{3} / \mathrm{m}^{3} / \mathrm{h}$, because the zone was not suffering from a problem of historic over-allocation.

Table 13. 2: Rationale to assess yearly allocation (source: DDT Tarn-et-Garonne, 2015).

\begin{tabular}{|c|c|c|c|c|}
\hline & \multirow{2}{*}{\multicolumn{2}{|c|}{$\begin{array}{c}\text { Zone } \\
13 \\
\text { Ga- } \\
\text { ronne }\end{array}$}} & \multirow{2}{*}{$\begin{array}{l}\text { Zone } \\
14 \\
\text { Tarn }\end{array}$} & \multirow[t]{2}{*}{ Unit } \\
\hline & & & & \\
\hline 1 & ${ }_{\mathrm{N}}$ Activated entitlements for year & 797 & 235 & $m^{3} / h$ \\
\hline 2 & $\begin{array}{l}\text { Dormant entitlements (possibly } \\
\text { activated year }>\mathrm{N} \text { ) }\end{array}$ & 251 & 27 & $m^{3} / h$ \\
\hline $3=1+2$ & Total entitlement & 1048 & 262 & $m^{3} / h$ \\
\hline 4 & Max. allocation in the basin & 833 & 686 & $m^{3} / m^{3} / h$ \\
\hline $5=3 \times 4$ & $\begin{array}{l}\text { Total maximum request (year } \\
\mathrm{N})\end{array}$ & $\begin{array}{l}872 \\
984 \\
\end{array}$ & $\begin{array}{l}179 \\
732\end{array}$ & $m^{3}$ \\
\hline 6 & $\begin{array}{l}\text { Max. Permissible Volume } \\
\text { (MPV) for year } \mathrm{N}\end{array}$ & $\begin{array}{c}284 \\
954 \\
\end{array}$ & $\begin{array}{r}249 \\
637 \\
\end{array}$ & $m^{3}$ \\
\hline $\begin{array}{l}7=\underset{6)}{\operatorname{Max}(5-} \\
\text { (5) }\end{array}$ & Excess request in volume & $\begin{array}{c}588 \\
030\end{array}$ & 0 & $m^{3}$ \\
\hline $8=5 / 6$ & Groundwater exploitation rate & $\begin{array}{l}306 \\
\%\end{array}$ & $72 \%$ & $\begin{array}{l}\% \text { of } \\
M P V\end{array}$ \\
\hline $\begin{array}{l}9=\operatorname{Min}(6 \\
/ 1,4)\end{array}$ & Allocation in year $\mathrm{N}$ & 358 & 686 & $m^{3} / m^{3} / h$ \\
\hline
\end{tabular}




\section{The emergence of collective management}

The implementation of the 2006 Water Act led to the creation of agricultural users' associations, known as collective management agencies (or OUGCs). As explained in Chapter 3, when the OUGCs were set up, all the individual entitlements were cancelled and replaced by a single authorisation, which was attributed to the OUGC and corresponded to the sum of the former individual entitlements. The OUGC was then responsible for designing its own rules to share the resource between its members.

In Tarn-et-Garonne, the alluvial plain was split between five OUGCs after the creation of the collective management agencies. The division corresponded to the main rivers catchment areas in the department. The number of management zones was reduced to 21 and their geographic perimeter was adjusted to match that of the OUGCs (Figure 13. 8). Water pumped from the riverside aquifers was still considered as surface water.

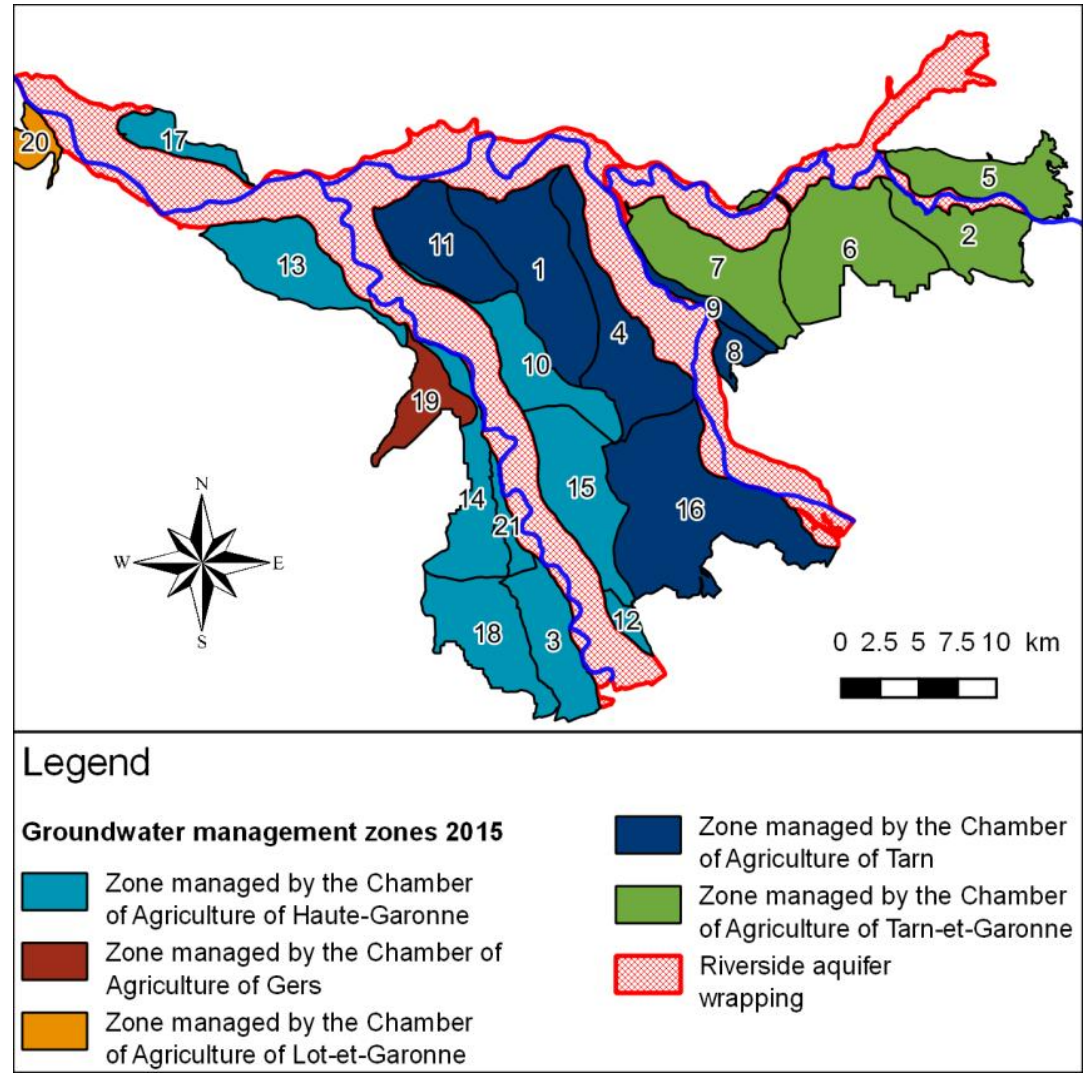

Figure 13. 8: Map of the 21 zones managed by the OUGCs, here, the departmental Chambers of Agriculture (source: Bardeau et al., 2016). 
The hydrogeological model was upgraded ${ }^{43}$, which improved its accuracy in terms of calculating the volumes for abstraction. One of the main changes was to ensure that a minimum groundwater level limit was built into the calculation. This level, set in each of the model's grid cells, corresponds to a baseline dry year.

The result of the new simulations involving years with very contrasting climates, shows that the volumes available for irrigation vary from 14 (in 2001-2002) to 130 million $\mathrm{m}^{3}$ per year (in 1992-1993) for all of the alluvial aquifers in the department. For the period 2006-2012, when the total requests for agricultural abstraction per management zone are compared to the permissible volumes, the model shows that the three driest climatic scenarios (minimum recharge, 20 dry years and 10 dry years) would trigger drastic reductions (up to 83\%) in one to five management zones. Management zones 17 and 21 are the most vulnerable to a low annual recharge. For the other wetter years of recharge (from 5 dry years to a year with maximum recharge ever observed), the current request for irrigation can be met in all of the management zones (Figure 13.9).

The management tool has also been improved with the calculation for recharge now built in. The user simply has to provide the data for rainfall and evapotranspiration. The new version is also capable of estimating the volumes that can be abstracted at three distinct dates: end of January (when the irrigation plans are submitted), end of March (before authorisations are allocated) and the start of June (to check whether the authorised volumes are consistent with the resource available).

Initially, the tool was only used by the state services. Later, it was transferred to the five OUGCs and used for allocating volumes of water to their members. The OUGCs adopted the rules for sharing the volume allocated, which had previously been applied by the state.

\footnotetext{
${ }^{43}$ The improvements include: the aquifer geometry, calculation of recharge, accounting for the fluctuations in the water levels in the rivers and reducing the modelling timestep from 2 months to 10 days (Bardeau et al., 2016; Thiéry, 2014). The model was recalibrated, using data from groundwater monitoring for the period 2005-2015 and validated for the period 1995-2015.
} 


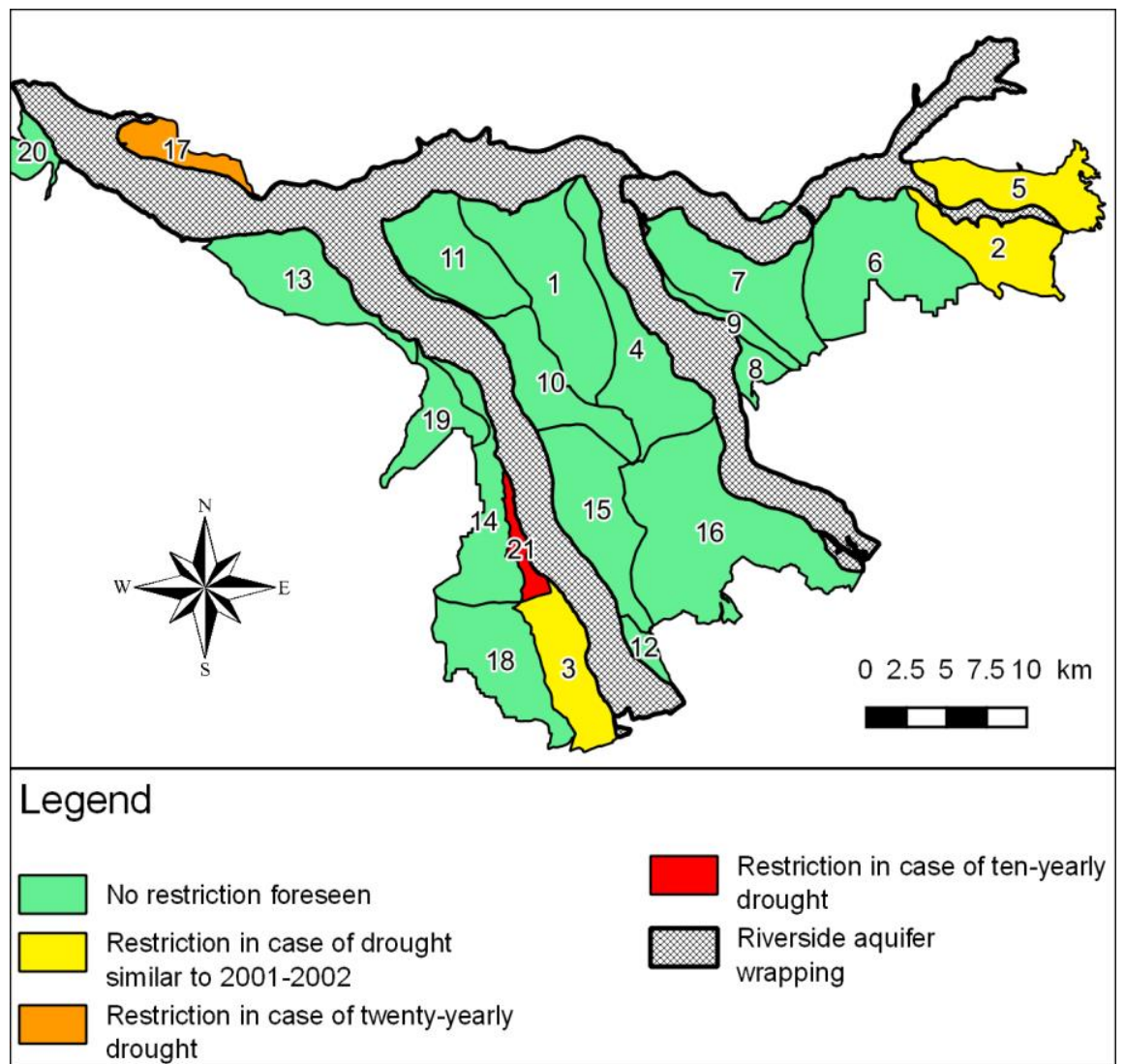

Figure 13. 9: Map of likely restrictions, based on abstraction levels that are similar to those for the period 2006-2012 (source: Bardeau et al., 2016).

\section{Conclusion}

The decision-making tool implemented for allocating water in the Tarn-et-Garonne department is the only one of its kind in France. Its main innovative feature is decoupling the management of entitlements (which define long-term access to a resource) from annual allocations. In theory, this means that crisis situations can be avoided because the volumes allocated are reduced in years when the groundwater levels are low at the start of the season. It also means that the volumes allocated can be increased when groundwater levels are extremely high. 


\subsection{Opportunities for improvement}

The quantitative management set up in Tarn-et-Garonne can be described as a process of continuous improvement over a period of 20 years. The stakeholders did not wait to acquire perfect knowledge of the aquifer before developing a model and a management tool. Gradually, both tools have been improved and this will continue as knowledge advances.

From a technical point of view, one possible improvement involves taking into account the real groundwater level at the start of the season when calculating the volume that can be abstracted (at the moment, the calculation relies on observed recharge alone). This would require installing a piezometer in each zone to determine more precisely the groundwater level in each zone.

From a societal point of view, one of the major issues is raising awareness amongst users about the tool - how it functions, the assumptions used for the calculations and the input data. This type of outreach is essential when it comes to encouraging farmers to accept the management rules and minimising the likelihood of conflicts in a dry year when volumes for abstraction are reduced. The aim is to provide farmers with Internet access to the groundwater records, supplemented with projected changes in the groundwater levels (as a function of the weather predictions). This would help each irrigator anticipate the amount of water available for the year and make an informed decision about crop choice and area.

Before this is achieved, making the tool available online is a first step. This would encourage OUGCs to adopt the tool and facilitate the management of the water resource available in the alluvial aquifer.

\subsection{Compliance and enforcement}

This chapter would be incomplete if the issue of compliance and enforcement was not addressed. In fact, although the state and its partners invested significant resources to develop knowledge and produce innovating management tools, it was far less effective in fulfilling its responsibility to monitor compliance and enforce regulations. The water policing services only monitor $1 \%$ of water meters each year. Their inspection is limited to checking whether the device is in place and working properly. The water policing services lack the means to carry out regular meter readings, which would allow them to determine whether the volumes declared by farmers correspond to the volumes actually pumped. Their operations are sometimes hindered by political interference. The lack of resources for effective enforcement is inconsistent with the highly sophisticated technical tools available.

Implementing a quantitative management plan for water resources takes time. This is one of the difficulties when it comes to applying regulations. In fact, the transition to volumetric management constitutes a revolution for most users who have always considered water as a freely available resource. A change in mentalities cannot be decreed, but must depend on training and raising awareness, which requires education. The state services are striving to achieve this, particularly with 
regard to the water policing services' mission. Most agents consider that their action should be gradual and that full compliance can only be achieved after a period of social learning, which may take 10 to 20 years. Thus in Tarn-et-Garonne when users default, the water policing services systematically apply sanctions progressively. The first time there is an infraction, the water policing services inform the offender of the regulations and offer to help them comply. For the second time, an official warning is issued (there is an administrative record of this in the case of recidivism). For the third time, and only then, legal proceedings are initiated.

\section{References}

Bardeau M., Le Cointe P. (2016). Gestion des systèmes aquifères alluviaux dans le bassin Adour-Garonne - Résultats de la modélisation et outil de gestion des prélèvements dans le Tarn-et-Garonne. BRGM Report/RP-65583-FR.

Bouroullec I. (2013). Carte géologique harmonisée du département du Tarn-etGaronne. BRGM Report /RP-61974-FR.

Collin J.J., Daum J.R. (1995). Méthodes d'évaluation de l'impact des prélèvements réalisés dans les nappes d'accompagnement sur les eaux superficielles associées. BRGM Report/R-38586.

Gandolfi J.M., Danneville L., Petit V., Tilloloy F. (1997). Connaissance, évaluation et protection des aquifères alluviaux de Tarn-et-Garonne (82). BRGM Report/R-39543.

Ghyselinck-Bardeau M. (2004a). Etude des aquifères alluviaux du Tarn-et-Garonne - Modélisation nappe-rivière en régime transitoire (Garonne, Tarn et Aveyron) - Intermediary report- Year 2. BRGM Report/RP-53207-FR.

Ghyselinck-Bardeau M. (2004b). Etude des aquifères alluviaux du Tarn-et-Garonne - Modélisation nappe-rivière en régime transitoire (Garonne, Tarn et Aveyron) - Final report - Year 2. BRGM Report/RP-53406-FR.

Ghyselinck-Bardeau M. (2007). Gestion des systèmes alluviaux dans le bassin Adour-Garonne - Modélisation de la nappe alluviale de la Garonne, du Tarn et de l'Aveyron dans le département de Tarn-et-Garonne - Final report. BRGM Report /RP-55315-FR

Ricard J. (1998). Gestion des systèmes alluviaux dans le bassin Adour-Garonne - Appui à la Police de l'Eau en Midi-Pyrénées - Mise en place des réseaux d'acquisition de données sur les aquifères alluviaux du Tarn-et-Garonne en vue de la réalisation d'un modèle en régime transitoire (phase 2 - tranche 1). BRGM Report/R-40364. 
Ricard J., Tilloloy F. (1999). Gestion des systèmes alluviaux dans le bassin Adour-Garonne - Appui à la Police de l'Eau en Midi-Pyrénées - Réseaux d'acquisition des données sur les aquifères alluviaux du Tarn-et-Garonne (phase 2 - tranche 2). BRGM Report/R-40731.

Saplairoles M. (2005). Etude des aquifères alluviaux du Tarn-et-Garonne - Présentation de l'outil de gestion issu de la modélisation en régime transitoire. BRGM Report/RP-54309-FR.

Soulé J.C. (1978). Evaluation des Ressources Hydrauliques de la France. Etat des connaissances et synthèse hydrogéologique du département de Tarn-et-Garonne. BRGM Report/78-SGN-070-MPY.

Thiéry D. (1990). Logiciel MARTHE - Modélisation d'Aquifère par un maillage Rectangulaire en régime Transitoire pour le calcul Hydrodynamique des Ecoulements. BRGM Report/R-32210.

Thiéry D. (2014). Logiciel GARDÉNIA, version 8.2. Guide d'utilisation. BRGM Reoprt/RP-62797-FR, update: May 2015.

Thiéry D. (2015). Code de calcul MARTHE - Modélisation 3D des écoulements dans les hydrosystèmes - Notice d'utilisation de la version 7.5. BRGM Report/RP64554-FR. 